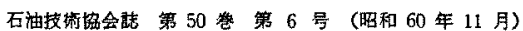

JOURNAI OF THE JAPANESE ASSOCIATION FOR PETROLEUM TECHNOLOGY

VOL. 50 , NO. 6 (Nov., 1985)

\author{
コアフラッディングテストにおける石油スルホネートの \\ 固液相互作用についで
}

\author{
津 村 雅 洋**
}

（明利60年9月12日受付，60年9月26日受理)

\title{
On Rock-Fluid Interaction of Petroleum Sulfonates in Core Flooding Test
}

By

Masahiro TSUMURA

\begin{abstract}
Dynamic adsorption tests of petroleum sulfonates were conducted using Berea core to study the effects of average EW of micellar slugs, cosurfactants, oil volume contained in micellar slugs and salinity as main factors which affect adsorption of sulfonates on rocks. The influence of divalent cations removed from the rock surface by ion exchange on sulfonates or micellar slugs were examined, and the correlation between phase behavior investigating fluid-fluid interaction and that of effuent samples including rock-fluid interaction in cores was studied. The effect of preflush of sodium orthosilicate solution was also investigated.

1) More hydrophilic slugs with lower EW showed less adsorption of sulfonates than higher EW slugs. Cosurfactants had the effect to reduce adsorption of sulfonates. More hydrophilic cosurfactants with larger HLB value are more effective to decrease adsorption. Increase of oil volume contained in slugs led to reduction of sulfonate adsorption.

2) Salinity had a great influence on sulfonate adsorption. Especially, salinity of a slug itself and salinity of a polymer solution which interacts with a slug seriously affected adsorption of sulfonates.

3) Microemulsion phase in cores shifted from lower phase to middle or upper phase. These transitions of microemulsion phase are attributed to formation of bonds between divalent cations removed from cores by ion exchange and sulfonates or micelles.

4) Adsorption of sulfonates was reduced considerably by the preflush of sodium orthosilicate solution. The preflush of sodium orthosilicate solution is considered to have the effect to restrain the formation of bonds between divalent cations and sulfonates.
\end{abstract}

\section{1.はじめに}

マイセラーポリマー攻法においては，その主要なケミ カルであるマイセラースラク（以下巣にスラグと略す） の性能をいが洔続さなるかといらことは, 最も重要な 問題の一つである。スラグの性能の少化は，泪娄流体と の浘合希釈，油層岩へのスルホネートの吸着に上る損 失，交たイオン交換により油層岩上り溶出した多価イ才 ンとスルホネートとの結合による界面活性の变化等様々 な要因が考えられる。

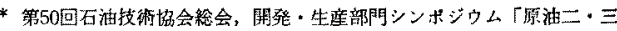
次回牧技術」以て赫演（昭租60年6月4日）

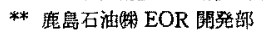

$$
\text { ここでは石油スルホネートを用いてベレアコアに対す }
$$
る動的吸着案験を行い, スラグの平均 $\mathrm{EW \dagger ，コサーフ}$ フタタント，あるいは塩分濃度等の因子がスルホネート の吸着にどのよらな影響を与えるのかを調へ，吸着量を 低減させる方向を探った。またコアょり溶出する二伹イ オンに注目し，それらの二洒イオンがスルホネートある いはスラダにどの上らな埧響を与えるのか，徒来の液一 液相互作用を扱っている相举動と固一液相互作用を含む コア内での流体挙動とがどのような関係にあるのかを調 ペた。フルカりを用いたプレフラッシュの好果を蛤討 し，スルホネートの吸着を㧕制するメカニズムについて

\footnotetext{
† EW (Equivalent Weight) の定获 $: \mathrm{EW}=$ 分子量/分子中のスルホ 基数
} 
考察した。

\section{2. 実験}

\section{1 試 料}

(1) ベレアュア

本夷験に使用したべレアコフは，浸透率が200 400 $\mathrm{md}$, 直径 $3.8 \mathrm{~cm}(1.5 \mathrm{in})$, 長さ約 $12 \mathrm{~cm}$ のニアタイプ の生ベレアコアである。

(2) 塩 水

コアの水飽和, 水攻, ポリマー溶液, 後押し水拈上び スラグ調製に使用した塩水は，特に断らない限り $\mathrm{NaCl}$ $4,000 \mathrm{ppm}$ 水溶液である。

スラク調製に使用したオイルは白灯油，軽油（以下各 タ WKO, GO と記す)であり、ュアに压入したオイル としては WKO, 流動バラフィンを使用した。これらの オィルの主な性状を表 1 に示した。

(4) 石油スルホネート

石油スルホネートとしてはぺトロステッブ PS-420, PS-465を用いた。表 2 にそれらの性状を示した。な出 ペトロステップはあらかじめ塩水心溶解し，20wt％溶 液として用いた。

(5) コサーファクタント

コサーファタタントとしてはエトキシレート系アルコ 一ルを使用した。

(6) ボリマー溶液

使用したボりマーはポリフクリルてミドでこれを篮
表1 使用したオイルの主な性状

\begin{tabular}{|l|c|c|c|}
\hline & WKO & GO & Liquid paraffin $^{11}$ \\
\hline Sp. Gr. $\left(15 / 4^{\circ} \mathrm{C}\right)$ & 0.7954 & 0.8329 & 0.8521 \\
\hline Vis. (cst $\left.30^{\circ} \mathrm{C}\right)$ & 0.57 & 1.44 & 30.48 \\
\hline
\end{tabular}

1) Kyodo Oil Co., No. 3 liquid paraffin

表 2 ペトロステップの性状

\begin{tabular}{|c|c|r|r|r|}
\hline & $\begin{array}{c}\text { Active } \\
(\text { wt. } \%)\end{array}$ & $\begin{array}{c}\text { Free Oil } \\
\text { (wt.\%) }\end{array}$ & $\begin{array}{c}\text { Salt } \\
(\text { wt. \%) }\end{array}$ & EW \\
\hline PS-420 & 56.1 & 13.0 & 2.1 & 417 \\
\hline PS-465 & 59.4 & 13.7 & 2.1 & 462 \\
\hline
\end{tabular}

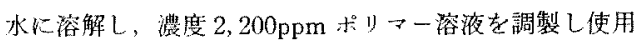
Lto

(7) ソレフラッシュ基材

プレフラッシュ基材としてはオルトタイ酸ナトリウム

$\mathrm{Na}_{4} \mathrm{SiO}_{4}$ を使用した。

\section{2 実験装置むよび操作}

\section{(1) 実験装置}

本実験に使用したコアフラッディソグ装置のフローの 概略圶图 1 に示した。

(2) 実験操作

実験の操作手順の概略を図 2 に示した。

(1) $\neg>の$ 塩水铇和

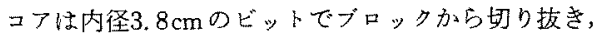

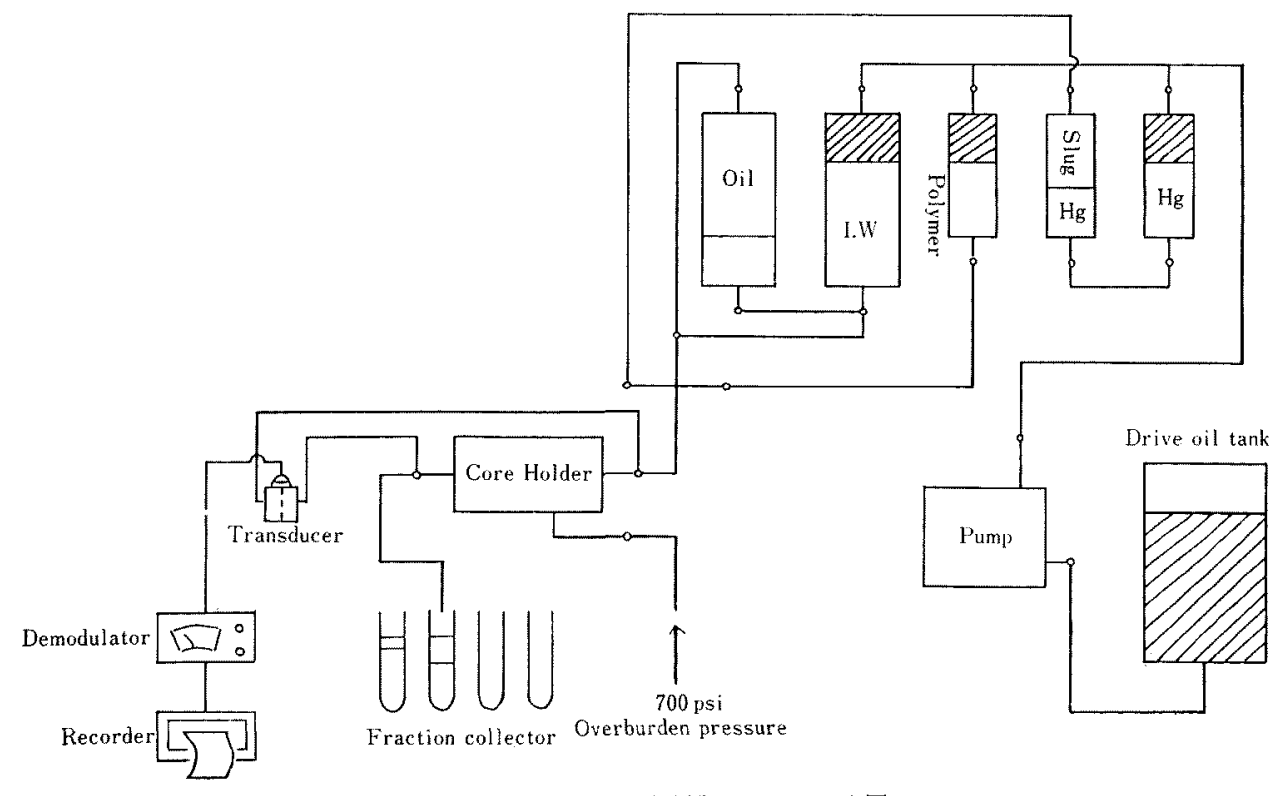

図 1 フラッディング装置のフロー概略図 


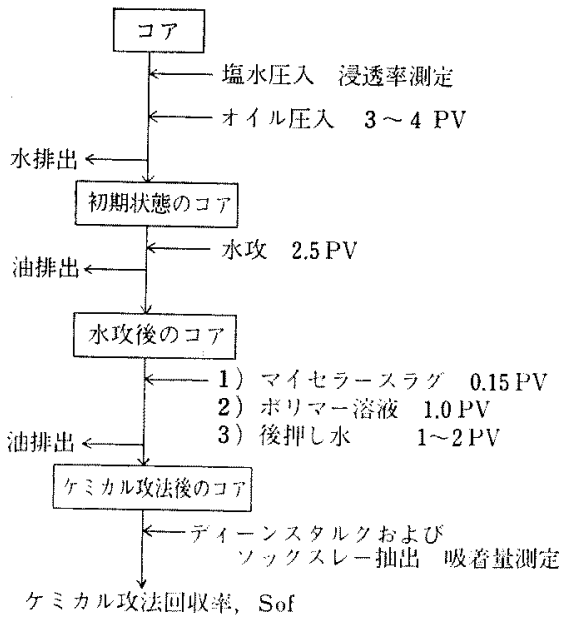

图 2 春㘊り操作手順

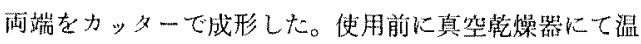
度䄪 $80^{\circ} \mathrm{C} て ゙ 2$ 時間嘪空乾燥させた後, 乾燥コフの重量之

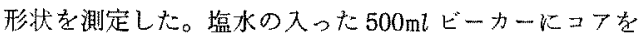
浸し，真空ポンプを用いて減圧し約 4 時間でュアの塩水 鴒和を完了させた。

(2) 漫透率测定

コアをホルダーにセットし, 約700psi $\left(4.83 \times 10^{8} \mathrm{~Pa}\right)$ のオーバーバーデン压かけた。塩水を買なった流速で

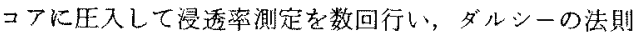
上り浸透察を求めた。

(3) オイ心置換

漫透率测定後, 約 $10 \mathrm{ft} / \mathrm{day}$ の流速でWKO または流動 バラフィンを約3.5PVE入してオイル置換を行った。こ の時排出される塩水の量を测定し，初期油慨和郭 $S_{o t}$ を 求めた。

(4) 水 功

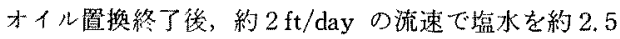
PV 压入し水攻法を行った。この時排出されるオイル罝 を湘定し，水攻法回収率括よび水攻後の油飽和率 $S_{o r}$ を 求めた。

(5) マイ七シー攻注

水攻終了後，䄪 $2 \mathrm{ft} /$ day の流速て大

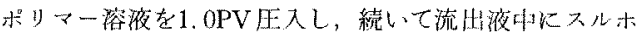

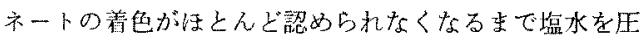
入した $(1 \sim 2 \mathrm{PV})$ 。流出液恃 $4 \sim 5$ 本の $25 \mathrm{ml}$ 有栓試験 管にとり，各フラタションの重量を湘定した。マイセラ 一攻法回取率，残留油铇和率 $S_{0}$ ，は次項で速べる抽出操 作就よびュフの熏量差より求めた。

(3）コアの抽出操作斿よび吸着量の测定
表 3 S-1〜S-4 の各スラダの組成, 形状

\begin{tabular}{|c|r|r|r|r|}
\hline Slug No. & S-1 & S-2 & S-3 & S-4 \\
\hline $20(\%)$ PS-420(g) & 40 & 30 & 30 & 15 \\
\hline $20(\%)$ PS-465(g) & 25 & 35 & 35 & 50 \\
\hline Oil (g) & WKO 10 & WKO 10 & GO 10 & GO 10 \\
\hline Brine (g) & 25 & 25 & 25 & 25 \\
\hline EW & 434 & 442 & 442 & 452 \\
\hline
\end{tabular}

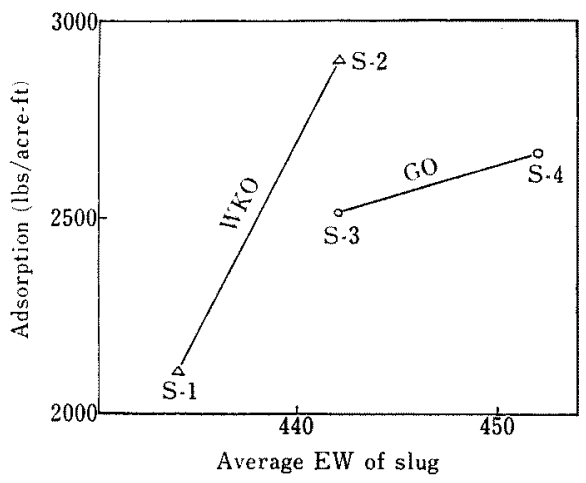

图 3 スラグの $\mathrm{EW}$ と吸着量

実験終了後のコアは，まずトルエンを用いてディーン スタルク抽出, 続いてンックスレ一抽出を行い、コフ中 の水分・油分を除くとともに，コア中にトラップされた スルホネートを抽出した。さらにその後クロロホルム・ メ夕ノールの湦合溶媒を用いてソックスレ一抽出を行 い,コアに睎着されたスルホネートを抽出した。

クロロホルム・ハタノール混合溶媒から改良ェブトン 法により抽出されたスルホネート量を求め,これをスル ホネートのコアへの吸着量とした。

流出液中の二価イオン濃度は原子吸光法により求め た。

\section{3. 結果と考察}

\section{1 スルホネートの财着に及ぼすスラグ因子の影響}

(1) スラグの平姆 $\mathrm{EW}$

スラグの平均 $\mathrm{EW} の$ 相息によりスルホネートの吸籍 媓がどのように変化するが調べるために，EWの買な るスラダ S-1〜S-4の吸着量を测定した。スラグ S-1〜 S-4の組成を表 $3 に$ にこれらのスラグの吸着量を図3に 示した。

図 3 よりスラグ S-1 と S-2間, S-3 と S-4問, すな わら同一オイルを同一量含んだスラグ間では，オイルの 種類によらず親水性である低 $\mathrm{EW}$ スラク゚の方が吸着量 
は少なく, 逆に高 $\mathrm{EW}$ スラグでは吸着量が増大してい る事が理解される。この結果は SANDVICKら"に上って 報告されている結果と闹样の傾向を示している。

EW の相違による吸着䍌の違いは，スラダ中のオイル として WKOを用いたスラグの方が EW と吸着量の間 の相関が大きく、およを10EW当たり，1,000lbs/acre-ft*, GOを用いたスラグでは10 EW 当たり200lbs/acre-ft て あった。

一力同一EW のスラダ S-2 と S-3間では、相挙動テ ストでは汪とんど同しよらな挙動を示すが，吸着星は約 $400 \mathrm{lbs} / \mathrm{acre}-\mathrm{ft}$ の差がある。これ同一EWでも分子量大 の $\mathrm{GO}$ を含むスラグ $\mathrm{S}-3$ の方か，分子觜小の WKO 含もスラグ $\mathrm{S}-2$ 上り，マイクロエマルジョンあるい ミ七ルとしてより親水性が強いこ上に起因すると考えら れる。現在のところスラグそのるのの親水性, 親油性を 定量的心測定するのは国難であるが，例党ば水を張った 試駼管に2つのスラグを静かに质わらせて滴下した時， スラグ S-3はすくにに水と均一に混台するがS-2は油のよ うな挙動をとり水と混合しにくいことからも2つのスラ グの親水性，視油性に差があることがわかる。したがっ て同一EW のスラダでも, 含有するオイルの分子量の違 いにより親水性，親油性に差が生じ，前述したと同様に 上り親水性のスラク゚の方が吸着量が減少するといらこと が推察される。

(2) コサーファクタント

図 4はコサーファタタントを含まないメラダをべース に，スラグ100gk対してェトキシレートフルコールET -127 (HLB 12) を1.0，2.0，3.0g 添加していった時の 吸着量の变化，また，ET-147，ET-167（各々HLB14,

16）を $1.0 \mathrm{~g}$ 添加した時のコサーファクタント種の相違 による吸着量の変化を表したものである。

コサーファクタントを添加したスラダは、コサーブ タタント無添加のスラダと比較して 300〜900 lbs/acre-ft の吸着量の減少が見られ、コサーファクタントがスルホ ネートの樶着を抑制していることがかかった。

一カュサーファクタント程の相逞に上る吸着量の差を 見ると，同じ量のコサーファクタントを㳢加しても，

HLBのより大きな, 寸なわちより親水性の強いコサー ファタタントのカがスルホネートの㛺着を抑制する圾果 は大きいといらことが壱える。

これらの結果からコサーファクタント添加の效果は， 主にスルホネートあるいはミセルが水中でより安定に溶 解あるいは分散するようになり，スラグがより親水性と なり（実際コサーファタタント添加により optimal salinity が増大した), 相対的にコア゙への吸着量が減少した

* $1 \mathrm{lbs} / \mathrm{acre}-\mathrm{ft}=0.368 \mathrm{~g} / \mathrm{m}^{3}$

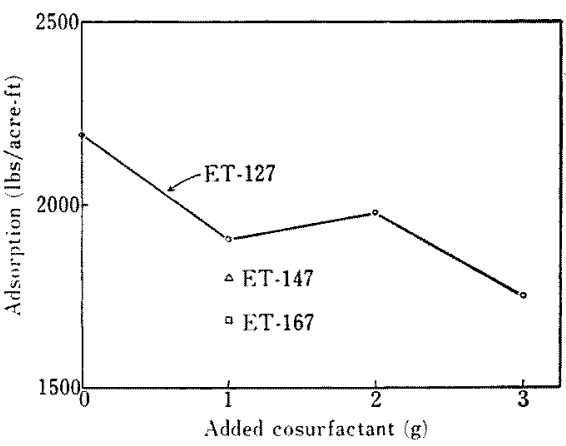

図 4 添加コサーフォタタント最と吸着媓の関係

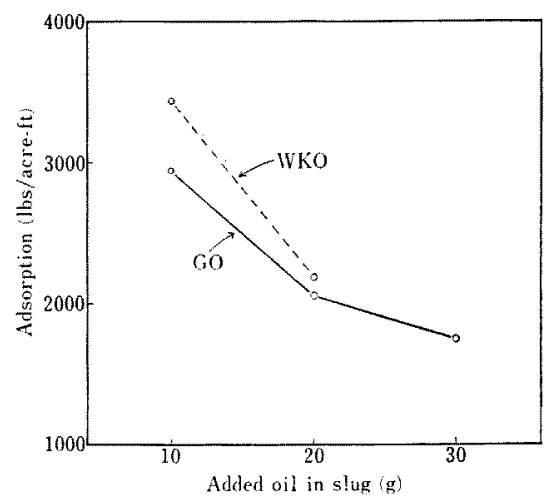

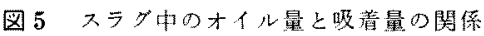

6のと思机れ。

(3) スラダ中のオイル量

图5はスラグ中に含まれる才イル量を10，20，30 gに 贸えた時の吸着量の変化を裁したるのである。

これらの結果からスラグ中のオイ山量を增大させると

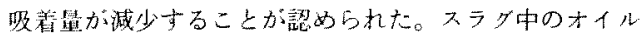
としてWKO，GO を用いたスラク゚ともにこの傾同が惩 められた。このラグ中のオイル量の䘫化がスルホネー

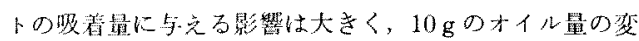
化て900 1, 000lbs/acre-ft の吸着䁷の減少を示した。

このようなスラダのオイル甾の增加によりスルホネー

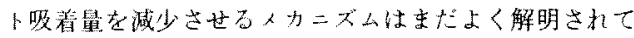

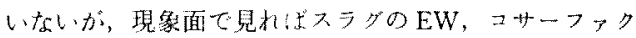
タントよりもその效果は大きく，スラグデザインを行ら 際には吸着を㧕制するための因子として重要なおのの1 つであると考えられる。

\section{(4) 塩分濃度の影響}

フラッディングテストに扎て，水攻水，スラグ，ポ

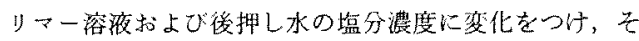
れらの壏分湄度がスルホネートの吸着によ゙のような影暗 


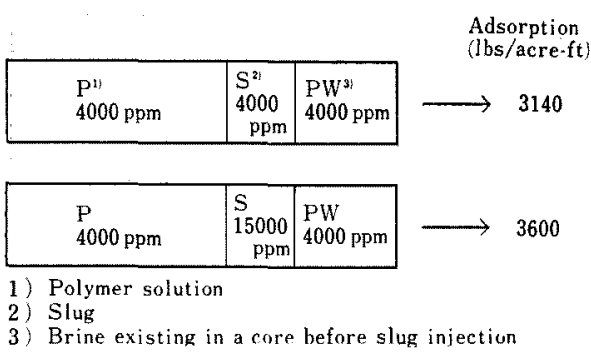

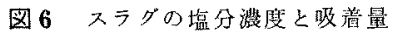

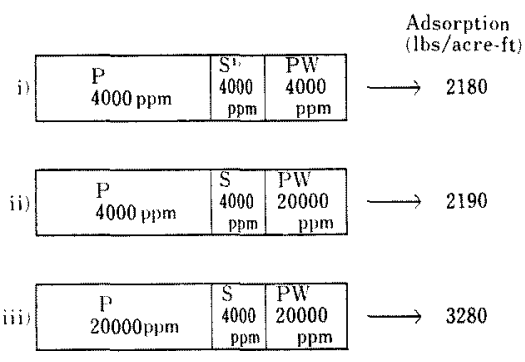

1) Formulation of this slug is different from that of the slug in Fig. 6.

图 7 水攻水, ポリマ一溶液, 後押し水の塩分濃度の 変化と吸潧量

を与えるかについて調バた。

图 6 はスラグの塩分濃度を $\mathrm{NaCl}$ 4,000ppmから15,000 ppmK変えた跱のスルホネートの吸着量の変化を表わし たものである。

図6からわかるよらに同一のペトロステップの配合で も塩分渄度を增加させたスラグでは，吸着量が約 $500 \mathrm{lbs} /$ acre-ft 增大している。これは前述のコサーファクタント 添加効果とは逆に，塩分の増加によりスルホネートある い性ミせルの水中に执ける溶解性・分散性が咸少し, 相 対的にコアへの吸着が増加したものと考えられる。

图 7 はスラグの塩分濃度は一定 $(\mathrm{NaCl} 4,000 \mathrm{ppm})$ に し，i）は水攻水，スラグ，ボリマ一溶激・後押し水の

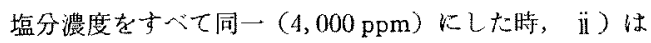

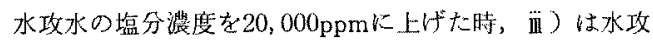
水とポリマー溶液・後押し水の塩分浱度を20,000ppmに 上げた時のスルホネートの吸着量の変化を示したもので ある。

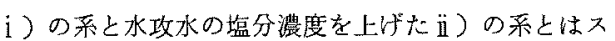
ルホネート吸着量にほとんど差が見られず，一力ボリマ 一溶渡・後押し水の塩分濃度を上げた五）の系では吸着 量が約 1, $100 \mathrm{lbs} /$ acre-ft 增大した。この結果は SHAH らによって報告されてい各結果と同様な傾向を示してい る。
これらの結果から程分浇度の变化による吸着量の相違 については，スラダ前面の塩水の塩分浱度よりも，むし ろスラグ自体の塩分濃度, スラグ後面のポリマー溶液と の希积，ミキシング等の相互作用時の塩分濃度がスルホ ネートの吸着に大きく影謷している事が指摘できる。

\section{2 コアとスルホネートの相互作用について}

(1)コアより容出した二洒イオンとスルホネートとの 結合について

スラタ7 S-1 (EW 434), S-4 (EW 452) は, 水攻水, ス ラグ䶂製用の熄水, ポリマ一溶液および後押し水の通常 の塩分濃度である NaCl 4,000ppm の条件下では，その 相挙動はともに lower phaseを示す。これらのスラグを 用いた動的吸着奏駼の流出液の相は S-1 では middle phase, S-4では upper phase になっていることが誌めら れた。このよらな相挙動の変化は, 他のスラグにおいて も同様に諗められた。

このようなスラグのコアへの王入前後に和ける相举動 の变化の原因を検討寸るために，スラグ $\mathrm{S}-4$ の流出液の 油相抢よび水相中の二洒イオン濃度を調べた。油相中の 二価イオンは ASTM D-3712 に準起した手法で調べた。 その結果を表 4 に示した。

表4から明らかなよらに上記のスラグあるいはスルホ ネートの相举勤の変化は，主にコア上り溶出した二洒个 オンとスルホネートあるいはミセルが結合し、スルホネ 一トあるいはミ七ルの油溶珄が増大したためと考えられ る。

一方スルネートの吸着に関しても，二価イオンとの 結合は吸着量が増大寸る方向に作用すると推察される。 一つには二洒イオンとの結合によりスルホネートあるい はミセルの水中での溶解性・分散性が低下しコアへ吸着 されやすくなることが教らられるまた一つには石英, 長石，粘土鉱物等の岩石表面は $\mathrm{pH}$ 中性の水中では負に 带電していると言われて掩り，ミセルが二洒イオンと一 部結合することにより，静䉓気的にもコアへ吸着されや おくなると洘点られる。

コア内の二価イオンを全てナトリウムイオンに置換す る目的で水攻水として約 $100 \mathrm{PV}$ 亿相然する酎の $\mathrm{NaCl}$ $4,000 \mathrm{ppm}$ 水溶液を王入したが，流出液中のカルシウム

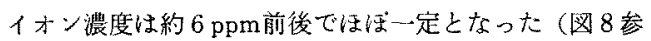
照)。

表 4 流出液中の二伯イホン漞度

\begin{tabular}{|c|c|c|}
\hline & Oil Phase (ppm) & Water Phase (ppm) \\
\hline $\mathrm{Ca}^{2+}$ & 150 & 38 \\
\hline $\mathrm{Mg}^{2+}$ & 190 & 27 \\
\hline
\end{tabular}




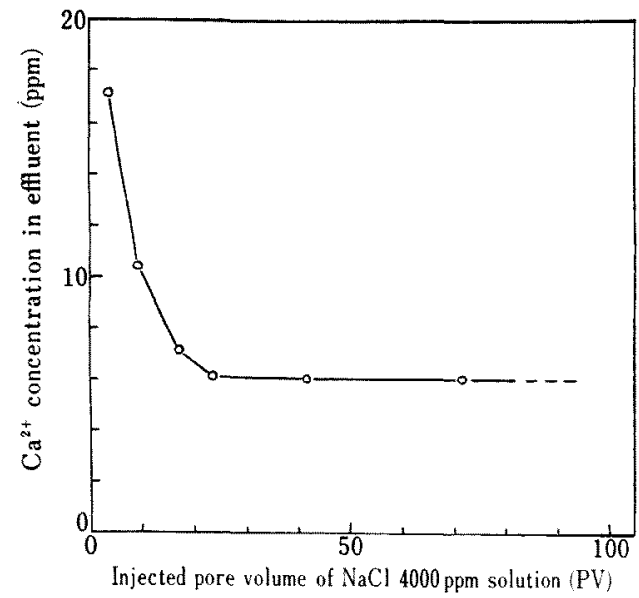

图 8 水政水古大量に王入した時の流出液中 $D \mathrm{Ca}^{2+}$, オンの澧度变化

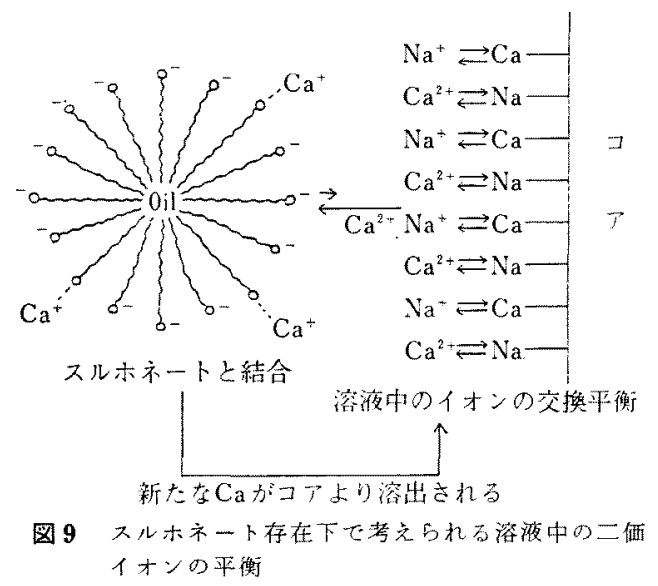

流出したカルシウムは合計 $19,000 \mu \mathrm{g}$ であったが、こ の值は使用したヘレアコフの CEC (Cation Exchange Capacity) の值 $(0.6 \sim 0.8 \mathrm{meq} / 100 \mathrm{~g}$-rock) 加敦算す ると交換し得る力テォン量の䄪半分に与ぎ。このこと

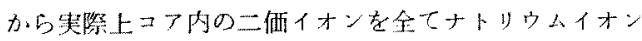
に置换することは不可能であると思われる。またこのよ 5 k大量の $\mathrm{NaCl}$ 水溶液を流してコア円に残存本る二何 イオン在低隇しても，スラダを国入すると新しい平衡

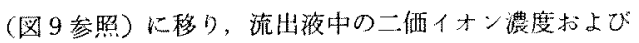
スルホネート吸着量は通常の $2 \sim 3 \mathrm{PV} の$ 水攻を行った 実験と比心，大きな变化はなかった。

スルホネートが存在することにより二価イオンの溶出

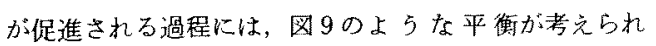
る。すなわb溶液中で $\mathrm{Na}^{+}$と $\mathrm{Ca}^{2+}$ とがある濃度で交換 平衡になっているところへスルホネートが加えられる

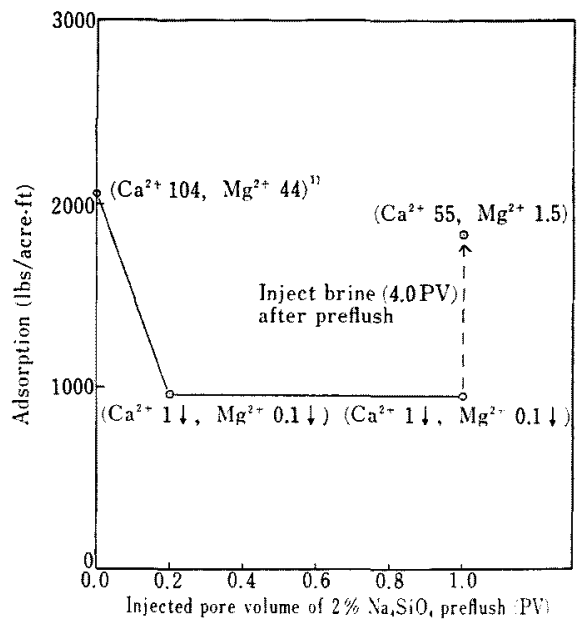

1) Values in parentheses show the concentration (ppm of divalent cations in effluent samples

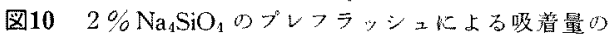
贸仙

と， $\mathrm{Ca}^{2+}$ とスルホネートあるいは、セルとの結台が生 じて溶液中の平衡がずれ新たにコア上り二洒イオンが溶 出され，流出液中のトータルの二価イオン濃度が増大寸 ると考えられる。

(2) オルトケ酸ナトリウムを用いたプレフラッシュ につ小て

オルトケイ酸ナトリウム $\left(\mathrm{Na}_{4} \mathrm{SiO}_{4}\right)$ を用いてそのプレ フラッシュの效果について調ベた。国10はプレフラッシ ュを行わなかった実唤と， $2 \% \mathrm{Na}_{4} \mathrm{SiO}_{4} を 0.2 \mathrm{PV}, 1.0$ PV 左入した後同し゚スグを任入した赛駼におけるスル ホネート吸著量の変化，また流出滩中の一洒ィなン激度 の変化を表したものである。

プレフラッシュを実施しなかった霓駼のスルホネート 吸着量に比ヘ，プレフラッンュを実施した春験では吸着

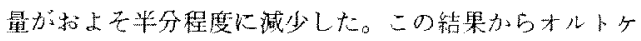
唒ナ゙トりムのプレフラッシュがスルホネートの吸着 を減少させるといら效果性白でる。

このよらにオルトケイ酸ナトリウムがスルホホートの 吸着老抑制す石效果としては主に二つのメ力二ズムが考

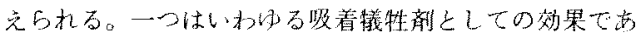
り，もら一つは自らが二便イオンと結合しスルホネ一ト と二洒イオンとの結合を掫制して吸着を低減させる効果 である。

流出湤中のカルンウムイオン震度の測定結果から、プ レフラッシュを実施した実験では流出液中にはとんど二 洒イオンが存在して括ず,オルトケ酸ナトリウムが スルホネートと三面イオンとの䋐合を揤俳しているのは 明らかである。 


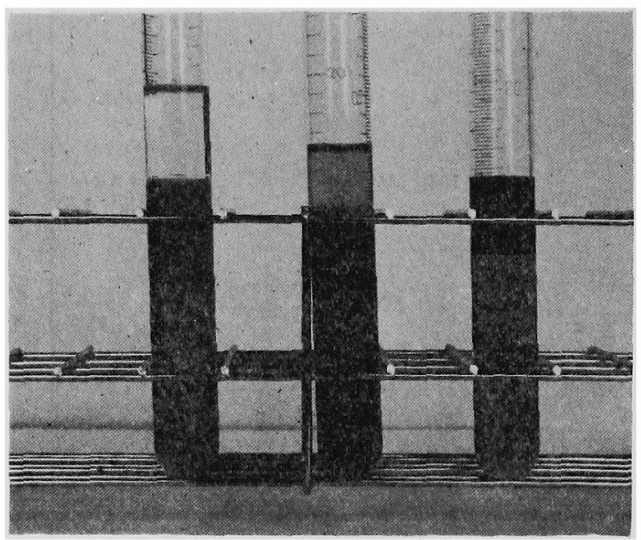

左：圧入前のスラグの相挙動

中：プレフラッシュを実施した実験の流出液の相挙 動

右：プレフラッシュを実施しなかった実験の流出液 の相挙動

写真 1 プレフラッシュ有無の実験に就ける流出液の 相の比較

また1.0PVの $2 \% \mathrm{Na}_{4} \mathrm{SiO}_{4}$ のプレフラッシュ実施後, 塩水を王入して流出液中の $\mathrm{pH}$ が強アルカリ $(\mathrm{pH} 12$ 前 後) からほとんど元の状態 ( $\mathrm{pH} 7$ 前後) になった後, スラグを压入した時のスルホネート吸着量を考えると (図10参照)，この時の吸着量はプレフラッシュを実施 しなかった実験に比べ約10\%の低減にとどまった。コア 中の吸着サイトに自らが強く吸着し, スルホネートの吸 着を低減させるといら吸着犠牲剤の働きから考皇ると， 塩水で水洗してもその効果は洰とんど変わらないと推察 される。

これらの結果を考台わせると，オルトケイ酸ナトリ ウムのプレフラッシュの効果は主にスルホネートと二価 イオンとの結合を抑制してスルホネートの吸着を低減さ せるものであると考党られる。

オルトケイ酸ナトリウムのこのよらな効果を考える と, 前に述べたスルホネートのコア内での相挙動の変化 も低减されるはずであり，プレフラッシュを象施した央 験の流出液の様子を調べた。

プレフラッシュを実施しなかった実験では压入前後の 相挙動の変化が著しいことは前述したが，プレフラッシ ュを実施した実験ではそれらの相変化がかなりの程度抑 えられ，元の相挙動と同じくスルホネートの大部分は lower phase に存在していることが認められた（写真1 参照)。同スラグは図 7 で用いたスラグに，ET-147をス ラグ $100 \mathrm{~g}$ 当たり $1.0 \mathrm{~g}$ 添加したものである。

したがってオルトケイ酸ナトリウムのプレフラッシュ はスルホネートと二価イオンとの結合を抑制しスルホネ
ートのコアへの吸着を低減するとともに, コア内でのス ラグあるいはスルホネートの相挙動に拈ける変化も抑え ていることがわかった。

\section{4. まとめ}

ベレアュアを用いて動的吸着実験を行い，スルホネー トの吸着に影響を与える主な因子としてスラグの EW， コサーファクタント，スラグ中に含有されるオイル量, 塩分濃度等の効果を検討した。コアより溶出する二価イ オンに注目し，それらの二価イオンがスルホネートある いはスラグにどのよらな影響を与兄っのか，従来の液一 液相互作用を調べている相挙動と固一液相互作用を含む コア内での流体挙動との関係について検討した。またオ ルトケイ酸ナトリウムのプレフラッシュの効果について 調べだ。

得られた知見としては

(1) ニサーファクタントを添加しないスラグでは，そ の平均 $\mathrm{EW}$ が低く,より親水性のもの注ど吸着量は少 ない。

コサーファタタントを添加するとスルホネートの吸着 は低下した。HLB の大きな，より親水性の強いコサー ファクタントほと吸着を抑制する効果は大きい。

スラグ中のオイル含有量を増加させるとスルホネート の吸着は減少し，その効果は $\mathrm{EW，コサーファクタント}$ 添加よりも大きい。

(2) 塩分濃度はスルホネートの吸着に大きな影響を与 方, 特にスラグ自体の塩分濃度, スラグ後面のポリマー 溶液との希釈，ミキシング等の相互作用時の塩分濃度が スルホネートの吸着に大きく影響している。

（3）コア内に拈けるマイクロエマルジョン相の挙動 は, lower $\rightarrow$ middle $\rightarrow$ upper $へ$ 之相変化する。この原因は 主にコアより溶出する二価イオンとスルホネートあるい はミセルとが結合することに由来すると考えられる。

(4) オルトケイ酸ナトリウムのプレフラッシュを行ら とスルホネートの吸着は低下した。このようなオルトケ イ酸ナトリウムのプレフラッシュは、コアより溶出する 二価イオンとスルホネートとの結合を抑制する効果があ ると考えられる。

\section{参 考 文 献}

1) GALE, W.W. and SANDvick, E.I., 1972: Tertiary Surfactant Flooding: Petroleum Sulfonate Composition-Efficacy Studies. SPE, 3804.

2) CHOU, S.I. and SHAH, D.O., 1981: Optimal Salinity of Polymer Solution in Surfactant-Polymer Flooding Process. In SHAH, D.O., ed.: Surface Phenomena in Enhanced Oil Recovery, 843-860, Plenum Press, New York. 